\title{
The Effect of Hotel Development on Sustainable Tourism Development
}

\author{
Ra'ed Masa'deh ${ }^{1}$, Mohammed Abdullah Nasseef ${ }^{2}$, Carina Sunna ${ }^{3}$, Mohammd Suliman ${ }^{4} \&$ Monther Albawab ${ }^{4}$ \\ ${ }^{1}$ Management Information Systems Department, School of Business, The University of Jordan, Amman, Jordan \\ ${ }^{2}$ Department of Business Administration, Faculty of Economics and Administration, King Abdulaziz University, \\ Jeddah, Saudi Arabia \\ ${ }^{3}$ Department of Tourism Management, Faculty of Tourism and Hospitality Management, The University of Jordan, \\ Aqaba, Jordan \\ ${ }^{4}$ Department of Hotel Management, Faculty of Tourism and Hospitality Management, The University of Jordan, \\ Aqaba, Jordan \\ Correspondence: Ra'ed Masa'deh, Management Information Systems Department, School of Business, The \\ University of Jordan, Amman, Jordan. Tel: 962-3-209-0450. E-mail: r.masadeh@ju.edu.jo
}

Received: June 4, 2017

Accepted: June 20, 2017

Online Published: June 27, 2017

doi:10.5430/ijba.v8n4p16

URL: https://doi.org/10.5430/ijba.v8n4p16

\begin{abstract}
This study aims to examine the impact of hotel development (using the variables of positive social and cultural impacts, negative cultural \& economic impacts, negative social impacts, community centered economic benefits, positive environmental impacts, government's environment management, positive economic impacts, long-term planning, community development \& involvement, amenities development \& quality tourism experiences, and local prices \& tax revenue) on sustainable tourism development at Aqaba hotels located in Jordan. A total of 170 questionnaire containing 44 items was used to collect information from the respondents. Simple regression, T-test, and ANOVA analyses were conducted to test the research hypotheses. Results of the current study revealed that there is a significant positive impact of hotel development on sustainable tourism development. Also, the results revealed that there is no significant difference in the impact of hotel development on sustainable tourism development that can be attributed to gender. Also, results indicated that there are no significant differences in the impact hotel development on sustainable tourism development in favor of age, educational level, personal income, work position, and hotel classification.
\end{abstract}

Keywords: hotel development, sustainable tourism development, Aqaba, Jordan

\section{Introduction}

Tourism, often describes as the movement of people away from home to other places of interest, it's one of the largest and fastest growing industries in the world, Travel and Tourism Council (Al-Badi et al., 2017). As an alternative form of export to other commodities, many countries of the world now adopt tourism as a major source of foreign exchange earnings (Zaiton \& Hassan, 2012). Sustainable tourism development concept is connected with specific issues for identification tourism development strategic tools upon sustainable regional development. By the UNESCO World Heritage Study, sustainable tourism, the concept of sustainable tourism development is related to principles such as intra- and inter- generational equity, has been widely applied to economic sectors, mainly and sustainable tourism (Rukuižienè, 2014). Sustainable tourism development means the optimal use of social, natural, cultural and financial resources for national development on an equitable and self-sustaining basis to provide a unique visitor experience and an improved quality of life through partnerships among local government, private sector and communities (Rukuižienè, 2014).

Hotels, as experienced by other businesses, are facing various external pressures (from communities, competitive forces and also governmental regulations) that push for environmentally friendly practices. In addition, the increase in environmentally mindful tourists reveals a future trend that could jeopardise the industry if environmental matters are not addressed. Moreover, commitment to environmentally friendly practices could lead to better organizational performance as indicated by several researchers (Siti-Nabiha, et al., 2014). In the context of the hotel industry, environmental management can be seen as the management influenced adoption of a continuous process by which a hotel's activities are monitored and suitable programs and activities implemented to reduce the negative impact on 
the environment (Mensah, 2006). Faulk (2000) declared that the first step towards a total quality environmental management system is the initial situation analysis of the organization's environmental practices to assess operational impacts, current attitudes and communications practices. Environmental practices which drive operations, programs and activities are the essential components in an environmental management system that seeks to protect, enhance and reduce the organization's impact on the environment (Siti-Nabiha, et al., 2014), however, focusing solely on environmental impact is not enough. Tourism should lead to the development of physical, economic and socio-cultural infrastructures that translates into regional development (Gartner, 1996). As such, research on the importance of the environment to the tourism industry is not complete without the inclusion of general development and more particularly, sustainable development issues (Siti-Nabiha, et al., 2014).

Since the early 1900s the concept of sustainability has attracted increasing attention in political, media and investment circles. In Ernst \& Young and the GreenBiz Group's recent review of trends in corporate sustainability strategy, for example, it was argued that "over the past two decades corporate sustainability efforts have evolved into a complex and disciplined business imperative focused on customer and stakeholder requirements". Many business leaders have been developing sustainability plans and programs as an increasingly important element of their corporate strategies. A number of factors help to explain this trend (Jones, et al., 2014). The lifestyle of the community's residents may influence the structural changes within the tourism industry occurring as a result of the ongoing development of tourism, such as changes in the local, social changes and environmental changes. A community that plans and uses tourism as an alternative means of strengthening its economic development must develop sustainable tourism to meet the needs and demands of its residents. The development of sustainable tourism is difficult without the support and participation of the community residents (Lee, 2013).

A new way of thinking about environmental responsibility is having an effect on the behavior of consumers when making purchasing decisions, influencing their reasons for travelling and the final choice of destination and service provider. Some authors highlight the fact that, providing the environmental setting is valued by clients, it becomes a differentiating output. Other authors consider environmental compliance as an element for improving the quality of the product and an attribute of the service provided by firms that has economic value for the consumer (García-Pozo, et al., 2013). A considerable amount of research has been done on sustainable tourism development in developed countries, but less on such development in island destinations. Similarly, local residents' perceptions of tourism development impacts have been examined, but less attention has been paid to the perceptions of tourism industry stakeholders. This study aims to fill some of the gaps in both areas of the literature (Prayag, et al., 2010). Sustainable development has been extensively discussed in tourism sectors because such development can meet the needs of tourists, provide opportunities to enhance economic growth, protect physical locations, and improve the quality of life of residents while enhancing opportunities for the future through the coexistence of tourism development and environmental quality. The United Nations World Tourism Organisation (UNWTO) states that sustainable tourism development should 'meet the needs of present tourists and host regions while protecting and enhancing opportunities for the future'. It should lead to 'the management of all resources in such a way that economic, social and aesthetic needs can be fulfilled while maintaining cultural integrity, essential ecological processes, biological diversity and life support systems' (Prayag, 2010; Lee, 2013).

Based on the researchers' experiences of working as a hotel guest service agent, we noted that there is a huge lack of interest in hotels and sustainable tourism practices, sustainable tourism education and awareness, lack of skills in identification and help to resolve environmental sustainability development challenges and impacts in local communities and hotel workers, managers and owners, lack of focus on the advantages of sustainable tourism management, as well as lack of support and encouragement for sustainable development from central and local governments, public sector, tourism and environmental organizations and business sector itself, also there is no effective implementation to resource management, conservation and long-term planning programs and this leads us to facing a lot of problem in development and sustainability and in order to eliminate them we need to drag owners, employees and local community attention on this problem throw this case study and the survey.

Furthermore, since few hotels that follow the standards of sustainable tourism, lack of full awareness about sustainable tourism in hotels, and lack of concern for the environment, which is an important part in our lives; this study aims to mainstream sustainability into tourism development by demonstrating the economic, environmental and socio-cultural benefits; contribute with biodiversity conservation; sustain of the well being local people; support people and organizational with learning experience; involve the responsible actions on the part of tourists and the tourism industry; and to deliver the products/services primarily to small groups by small-scale businesses. 


\section{Literature Review}

Tourism industry takes full account of its current and future economic, social and environmental impacts, addressing the needs of visitors, the industry, the environment and host communities. The most clearly declaration about sustainable tourism development concept was explained in 1997 Sustainable Over 170 states agreed to pursue at the United Nations Conference on Environment and Development in Rio de Janeiro in 1992, and possessed new challenges for environmental policy at both European and global level. The European Union and the Council of Europe have developed specific activities in this area. In 1995, the United Nations Environment Program by UNEP in Paris published for the first time a collection of the environmental guidelines in existence throughout the world for the tourist sector. In April 1995, UNESCO held a World Conference on Sustainable Tourism in Lanzarote.

Sustainable development has been extensively discussed in tourism sectors because such development can meet the needs of tourists, provide opportunities to enhance economic growth, protect physical locations, and improve the quality of life of residents while enhancing opportunities for the future through the coexistence of tourism development and environmental quality. Thus, community-based tourism development has become an important tool for sustainable management (Lee, 2013). World Trade Organization (WTO) suggests the definition such as the sustainable tourism development concept could include the regional development dimension in host regions while protecting and enhancing opportunities for it in the future. It is envisaged as leading to management of all resources in such a way that economic, social and aesthetic needs can be fulfilled while maintaining cultural integrity, essential ecological processes and biological diversity and life support systems.

Social exchange theory has been used to assess the support of residents for tourism development. The residents of a community decide whether to become dependent on the benefits and costs of tourism by weighting economic, social, cultural, and environmental concerns. Based on this theory, if the host residents perceive that they are likely to benefit from such exchanges without incurring intolerable costs, then these residents are likely to support and participate in exchanges with visitors and to support additional community-based tourism development (Lee, 2013).

In the context of the hotel industry, environmental management can be seen as the management influenced adoption of a continuous process by which a hotel's activities are monitored and suitable programs and activities implemented to reduce the negative impact on the environment, declared that the first step towards a total quality environmental management system is the initial situation analysis of the organization's environmental practices to assess operational impacts, current attitudes and communications practices. Environmental practices which drive operations, programs and activities are the essential components in an environmental management system that seeks to protect, enhance and reduce the organization's impact on the environment (Siti-Nabiha, et al., 2014). However, focusing solely on environmental impact is not enough. Tourism should lead to the development of physical, economic and socio-cultural infrastructures that translates into regional development. As such, research on the importance of the environment to the tourism industry is not complete without the inclusion of general development and more particularly, sustainable development issues. Understanding the impact of tourism on the environment should involve examining multi-disciplined development, and needs to include both social and economic concerns. The implication is that the environment covers a wide range of dimensions and relates not only to social involvement in the local community but also economic issues relating to organizational interactions with customers and other stakeholders (Siti-Nabiha, et al., 2014). In Malaysia, research on environmental management practices in hotels is limited with most studies having a focus on specific areas like environmental awareness and impact, environmental management practices of small and medium sized hotels and elements influencing environmental responsibility. For example, explored the awareness and attitudes of small and medium hotel managers in Kuala Lumpur (Malaysia) towards environmental management. She found that there was a lack of adequate knowledge about environmental management and most hotels did not go beyond practices that reduced their water and energy costs. The lack of environmental actions was due to the perception that such actions might affect the assurance of exceptional service quality and consequently lower guests' satisfaction (Siti-Nabiha, et al., 2014).

The United Nations World Tourism Organization (UNWTO) states that sustainable tourism development should 'meet the needs of present tourists and host regions while protecting and enhancing opportunities for the future'. It should lead to 'the management of all resources in such a way that economic, social and aesthetic needs can be fulfilled while maintaining cultural integrity, essential ecological processes, biological diversity and life support systems'. Therefore, tourism sustainability 'can be viewed as a set of principles, political prescriptions and management methods that establish a path to develop tourism in conjunction with the protection of the environmental, cultural and infrastructural resources of tourist destinations for the future' (Prayag, et al., 2010). Over the years, the concept of sustainable tourism has come to mean many things to many people. The researcher argues 
that sustainable tourism is an adaptable paradigm allowing for different development pathways and requires adaptation to the specific local conditions and needs. Local people should be given the responsibility for defining their own needs and planning their own course to sustainability. This local context definition of sustainable tourism leads to a development continuum ranging from very strong to very weak sustainable development. Suggests that sustainable tourism must not be a means to compete for resources to sustain tourism but rather it must seek the most appropriate and efficient ways to share resources within an overall development goal. In this way, a holistic approach is taken to tourism development and, through dynamic tourism policies, positive impacts are increased while negative ones are mitigated. In fact, for SIDS, sustainable tourism development should contribute to poverty reduction, income redistribution, betterment of the status of women and children, local mediation, conflict resolution and peace building (United Nations Environment Program. Prayag et al. (2010) argued that the direct and indirect economic benefits of tourism may have many positive social and cultural impacts, including employment, improved standards of living and health, and educational opportunities, promotion of arts and crafts, and environmental awareness in local communities. However, there is underlying social and cultural erosion that happens over time with the appearance of traffic congestion, noise pollution, crime and loss of cultural identity. Consequently, the 'Mauritius Strategy 05' recommends greater local community involvement and participation in tourism planning and development. This increased concern for social sustainability, i.e. the ability of a community to absorb visitors for either long or short periods of time without being influenced negatively by people different from themselves, is becoming an increasingly important driver of tourism development. Full community participation is said to occur when communities supply the majority of goods and services to tourists, have considerable input into planning decisions and collectively manage common resources. Also, vital to local communities is responsible behavior on the part of the visitor and the prevention of any form of distortion of the local culture (Prayag, et al., 2010).

In co-operation with the Spanish government, the participants adopted an 18-point charter for sustainable tourism, which had a significant impact. The first example of an international legal instrument can be found in the implementing Protocol on Tourism of the Convention for the Protection of the Alps, which commits the eight Alpine states to the goal of sustainable tourism in the Alpine region (Rukuižiene, 2014). Sustainable tourism development definitely includes the issues connected to the rural development, environmental impacts, cultural and natural heritage, services and infrastructure for tourism as ethnotourism orecotourism, or agrotourism, and alternative activities in countryside (Rukuižienè, 2014).

\section{Research Methodology}

This section provides the methodology applied in the current study. It consists of the research model, operational definitions of the study's independent and dependent variables, research hypotheses, besides data collection tool and research population and sample.

\subsection{Research Model}

The elements of this research are established based on preceding literature, either theoretically or empirically. Indeed, this study used variables that are common in ecotourism literature. Figure 1 represents a model for the study that shows the relationship between the research independent variable, the dependent variable, and the moderating ones. 


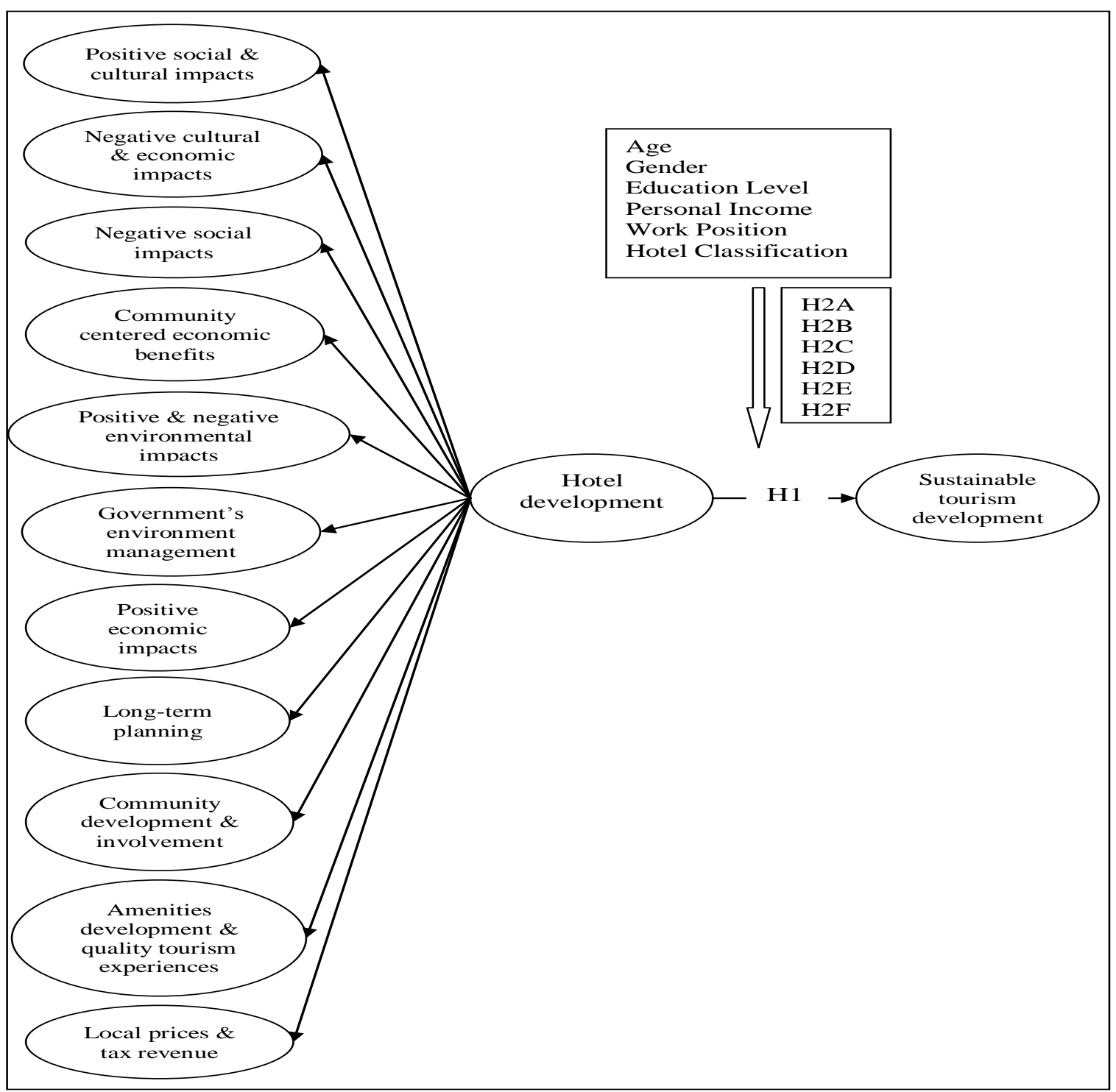

Figure 1. Research Model

\subsection{Operational Definitions}

Adapted from Prayag, et al. (2010), the current research considers eleven dimensions towards hotel development. These dimensions are positive social and cultural impacts, negative cultural \& economic impacts, negative social impacts, community centered economic benefits, positive environmental impacts, government's environment management, positive economic impacts, long-term planning, community development \& involvement, amenities development \& quality tourism experiences, and local prices \& tax revenue; which were measured in the research questionnaire through seven, four, four, four, three, four, four, two, two, three, and two items respectively. Also, sustainable tourism development, the dependent variable, adapted from Lee (2013) and measured through five items.

\subsection{Research Hypotheses}

In order to test the research model of the impact of hotel development on sustainable tourism development, the study is hypothesized as follows:

H1: There is a statistically significant impact of hotel development on sustainable tourism development.

$\mathrm{H} 2 \mathrm{~A}$ : There is a significant difference in the impact of hotel development on sustainable tourism development due to gender. 
H2B: There is a significant difference in the impact of hotel development on sustainable tourism development due to age.

$\mathrm{H} 2 \mathrm{C}$ : There is a significant difference in the impact of hotel development on sustainable tourism development due to educational level.

H2D: There is a significant difference in the impact of hotel development on sustainable tourism development due to personal income.

H2E: There is a significant difference in the impact of hotel development on sustainable tourism development due to work position.

H2F: There is a significant difference in the impact of hotel development on sustainable tourism development due to hotel classification.

\subsection{Population and Sampling}

The targeted population of this study consisted of all hoteliers involved in decision making that is, top and middle management in Aqaba Jordan. These are individuals most likely to influence a hotel's orientation towards sustainable practices. The official list of hotels employees supplied by The Ministry of Tourism and Antiquities. In 2015, this list comprised of 2384 hotel employees in Aqaba Jordan, a covering letter and the questionnaire were delivered to all hotels for a member of top management (e.g. CEOs, general manager, financial controller) or middle management (e.g. marketing manager, guest relations manager, room division manager, front office manager). Thus, a convenience sampling technique was conducted. However, 275 survey questionnaires were returned from respondents and considered 170 after eliminating the incomplete ones. The primary data was collected through a drop-and-collect survey technique. The questionnaire consisted of two sections; the first section in questionnaire presents general personal information about a respondent, the gender, age, education level, monthly income, work position and hotel rank. The second section includes questions to measure the extent of the hotel management development of sustainable tourism of Aqaba city.

\section{Data Analysis and Results}

In order to explore the impact of hotel development on sustainable tourism development, in which these variables have been measured using 5-points Likert scale that varies between strongly disagree $=1$ and strongly agree $=5$; except negative cultural \& economic impacts, and negative social impacts were reversed. Also, reliability and validity analyses were conducted; descriptive analysis was used to describe the characteristic of sample and the respondent to the questionnaires besides the independent and dependent variables. Also, simple regression analysis, Independent Samples T-test, and ANOVA test were employed to test the research hypotheses.

\subsection{Validity and Reliability}

Validity and reliability are two important measures to determine the quality and usefulness of the primary data. Validity is about accuracy and whether the instrument measures what it is intended to measure while reliability is about precision; it is used to check the consistency and stability of the questionnaire. Indeed, the researchers depended on scales and items that were previously developed and used by other researchers with similar interest. Also a draft of the questionnaire was formulated, and then it was reviewed by four academic lecturers -who have a sufficient knowledge and experience in this scope- to insure that each item is measuring what is intended to be measured, and to avoid the ambiguity and complexity in the phrasing of questions. The reliability of the instrument was measured by the Cronbach's alpha coefficient. Further, some scholars (e.g. Bagozzi \& Yi, 1988; Creswell, 2009) suggested that the values of all indicators or dimensional scales should be above the recommended value of 0.60. Table 1 represents the results of Cranach's alpha for the independent and dependent variables. Cronbach's alpha coefficients of all the tested variables are above 0.60 which suggesting the composite measure is reliable. 
Table 1. The Cronbach's alpha coefficients of study variables

\begin{tabular}{lcc}
\hline Variables & Number of items & Cronbach alpha \\
\hline Positive social and cultural impacts & 7 & 0.769 \\
\hline Negative cultural \& economic impacts (Reversed) & 4 & 0.709 \\
\hline Negative social impacts (Reversed) & 4 & 0.804 \\
\hline Community centered economic benefits & 4 & 0.713 \\
\hline Positive environmental impacts & 3 & 0.752 \\
\hline Government's environment management & 4 & 0.853 \\
\hline Positive economic impacts & 4 & 0.773 \\
\hline Long-term planning & 2 & 0.798 \\
\hline Community development \& involvement & 2 & 0.836 \\
\hline Amenities development \& quality tourism experiences & 3 & 0.886 \\
\hline Local prices \& tax revenue & 2 & 0.759 \\
\hline Sustainable tourism development & 5 & 0.864
\end{tabular}

\subsection{Respondents Demographic Profile}

As indicated in Table 2, the demographic profile of the respondents for this study showed that they are typically males, most of them less than 30 years old, and the majorities hold bachelor degrees, earn more than 500 JD (750\$ per month), most of them directors, and work in three-five star hotels.

Table 2. Description of the respondents' demographic profiles

\begin{tabular}{|c|c|c|c|}
\hline Category & Category & Frequency & Percentage\% \\
\hline \multirow[t]{3}{*}{ Gender } & Males & 165 & 971 \\
\hline & Females & 5 & 2.9 \\
\hline & Total & 170 & 100 \\
\hline \multirow[t]{5}{*}{ Age } & 18 years - less than 25 & 28 & 16.5 \\
\hline & 25 years - less than 30 & 75 & 44.1 \\
\hline & 30 years - less than 40 & 58 & 34.1 \\
\hline & More than 40 years old & 9 & 5.3 \\
\hline & Total & 170 & 100 \\
\hline \multirow[t]{6}{*}{ Education level } & High school & 33 & 19.4 \\
\hline & Diploma & 29 & 17.1 \\
\hline & Bachelor & 108 & 63.5 \\
\hline & Master & 0 & 0 \\
\hline & Doctorate & 0 & 0 \\
\hline & Total & 170 & 100 \\
\hline \multirow{4}{*}{$\begin{array}{l}\text { Personal income (JD) } \\
\text { per month }\end{array}$} & Less than 500 & 20 & 11.8 \\
\hline & 500 - less than 1000 & 101 & 59.4 \\
\hline & More than 1000 & 49 & 28.8 \\
\hline & Total & 170 & 100 \\
\hline \multirow[t]{5}{*}{ Work position } & Head of Department & 61 & 35.8 \\
\hline & Director & 80 & 47.1 \\
\hline & Executive Manager & 1 & 0.6 \\
\hline & Supervisor & 28 & 16.5 \\
\hline & Total & 170 & 100 \\
\hline \multirow[t]{6}{*}{ Hotel classification } & One Star & 0 & 0 \\
\hline & Two Star & 0 & 0 \\
\hline & Three Star & 49 & 28.8 \\
\hline & Four Star & 68 & 40.0 \\
\hline & Five Star & 53 & 31.2 \\
\hline & Total & 170 & 100 \\
\hline
\end{tabular}




\subsection{Descriptive Analysis}

In order to describe the responses and thus the attitude of the respondents toward each question they were asked in the survey, the mean and the standard deviation were estimated. While the mean shows the central tendency of the data, the standard deviation measures the dispersion which offers an index of the spread or variability in the data (Pallant, 2005; Sekaran \& Bougie, 2013). In other words, a small standard deviation for a set of values reveals that these values are clustered closely about the mean or located close to it; a large standard deviation indicates the opposite. The level of each item was determined by the following formula: (highest point in Likert scale - lowest point in Likert scale) / the number of the levels used $=(5-1) / 5=0.80$, where 1-1.80 reflected by "very low", 1.81-2.60 reflected by "low", 2.61-3.40 reflected by "moderate", 3.41-4.20 reflected by "high", and 4.21-5 reflected by "very high". Then the items were being ordered based on their means. Tables 3 and 4 show the results.

Table 3. Overall mean and standard deviation of the study's variables

\begin{tabular}{clccc}
\hline $\begin{array}{c}\text { Type of } \\
\text { Variable }\end{array}$ & Variables & Mean & Standard Deviation & Level \\
\hline $\begin{array}{c}\text { Independent } \\
\text { Variables }\end{array}$ & Hotel development & 3.60 & 0.83 & High \\
\hline & Positive social and cultural impacts & 3.68 & 0.83 & High \\
\hline & Negative cultural \& economic impacts (Reversed) & 2.05 & 0.86 & Low \\
\hline & Negative social impacts (Reversed) & 1.94 & 0.82 & Low \\
\hline & Community centered economic benefits & 3.98 & 0.81 & High \\
\hline & Positive environmental impacts & 3.90 & 0.89 & High \\
\hline & Government's environment management & 4.02 & 0.89 & High \\
\hline & Positive economic impacts & 4.03 & 0.88 & High \\
\hline & Long-term planning & 4.01 & 0.87 & High \\
\hline & Community development \& involvement & 3.95 & 0.89 & High \\
\hline & Amenities development \& quality tourism experiences & 3.96 & 0.85 & High \\
\hline $\begin{array}{c}\text { Dependent } \\
\text { Variable }\end{array}$ & Sucal prices \& tax revenue & 4.02 & 0.88 & High \\
\hline
\end{tabular}

As presented in Table 3, data analysis results have shown hotel development in Aqaba hotels is applied to a high level in which the mean score is 3.60. Further, sustainable tourism development does exist highly to a greater extent which the mean score is 4.03 . Table 4 demonstrates the mean, standard deviations, level, and order scores for resident attitudes towards ecotourism benefits items for each variable. 
Table 4. Mean and standard deviation of the study's variables

\begin{tabular}{|c|c|c|c|c|}
\hline Positive social and cultural impacts & Mean & SD & Level & Order \\
\hline $\begin{array}{l}\text { Hotel development should encourage government to improve roads and other public } \\
\text { facilities to maintain a high standard for tourism }\end{array}$ & 3.99 & 0.81 & High & 3 \\
\hline $\begin{array}{l}\text { Hotel development should encourage local communities to develop a variety of } \\
\text { cultural activities }\end{array}$ & 3.97 & 0.84 & High & 4 \\
\hline $\begin{array}{l}\text { Hotel development should encourage a closer cultural exchange between tourists and } \\
\text { local communities }\end{array}$ & 4.01 & 0.85 & High & 2 \\
\hline $\begin{array}{l}\text { Hotel development should encourage local communities to strengthen their cultural } \\
\text { identity }\end{array}$ & 4.03 & 0.86 & High & 1 \\
\hline $\begin{array}{l}\text { Hotel development should provide incentive for local communities to conserve } \\
\text { natural resources }\end{array}$ & 3.88 & 0.90 & High & 6 \\
\hline Hotel development should provide incentives for locals to preserve their local culture & 3.95 & 0.83 & High & 5 \\
\hline $\begin{array}{l}\text { Proper hotel development requires that wild life and natural habitat be protected at } \\
\text { all times }\end{array}$ & 2.98 & 0.82 & $\begin{array}{c}\text { Mode } \\
\text { rate }\end{array}$ & 7 \\
\hline Negative cultural \& economic impacts (Reversed) & Mean & SD & Level & Order \\
\hline Hotel development may change the culture of some communities & 2.00 & 0.82 & Low & 2 \\
\hline Hotel development may negatively affect local communities' way of life & 2.15 & 0.87 & Low & 4 \\
\hline $\begin{array}{l}\text { Hotel development may put more pressure on local services such as public utilities } \\
\text { and roads }\end{array}$ & 2.13 & 0.92 & Low & 3 \\
\hline Hotel development makes beaches unpleasantly overcrowded for local residents & 1.94 & 0.78 & Low & 1 \\
\hline Negative social impacts (Reversed) & Mean & SD & Level & Order \\
\hline Hotel development is likely to increase crime rate in a local area & 1.96 & 0.83 & Low & 3 \\
\hline Hotel development is likely to result in traffic congestion in a local area & 2.01 & 0.80 & Low & 4 \\
\hline Hotel development is likely to lead to more vandalism in an area & 1.92 & 0.87 & Low & 2 \\
\hline Hotel development is likely to result in more noise and pollution & 1.89 & 0.87 & Low & 1 \\
\hline Community centered economic benefits & Mean & SD & Level & Order \\
\hline $\begin{array}{l}\text { Hotels should be required to obtain half their goods and services from within the } \\
\text { local community }\end{array}$ & 4.10 & 0.82 & High & 1 \\
\hline Hotels should hire at least half their employees within the local community & 3.94 & 0.84 & High & 3 \\
\hline Hotels must contribute to community improvement funds & 4.02 & 0.80 & High & 2 \\
\hline $\begin{array}{l}\text { Hotel development should provide more income for local population and local } \\
\text { communities }\end{array}$ & 3.88 & 0.80 & High & 4 \\
\hline Positive environmental impacts & Mean & SD & Level & Order \\
\hline $\begin{array}{l}\text { Government should further encourage hotel developers to protect community } \\
\text { environment and natural resources }\end{array}$ & 3.89 & 0.87 & High & 2 \\
\hline $\begin{array}{l}\text { Government should control tourism development, including hotel development, to } \\
\text { limit environmental degradation }\end{array}$ & 3.79 & 0.92 & High & 3 \\
\hline Hotel development should be in harmony with natural and cultural environment & 4.05 & 0.79 & High & 1 \\
\hline Government's environment management & Mean & SD & Level & Order \\
\hline $\begin{array}{l}\text { Government and hoteliers should encourage a more integrative approach to } \\
\text { environmental quality enhancement of the destination }\end{array}$ & 4.06 & 0.82 & High & 2 \\
\hline $\begin{array}{l}\text { Government and hoteliers should further strengthen efforts for environmental } \\
\text { conservation }\end{array}$ & 4.09 & 0.79 & High & 1 \\
\hline $\begin{array}{l}\text { More stringent regulatory environmental standards are needed to reduce negative } \\
\text { impacts of hotel development }\end{array}$ & 4.02 & 0.81 & High & 3 \\
\hline Government should ensure that positive environmental eth & 3.94 & 0.78 & High & 4 \\
\hline
\end{tabular}


all tourism stakeholders

\begin{tabular}{|c|c|c|c|c|}
\hline Positive economic impacts & Mean & SD & Level & Order \\
\hline Hoteliers must embrace the values of community residents & 4.00 & 0.82 & High & 3 \\
\hline $\begin{array}{l}\text { Hotel development should create more business for local people and } \\
\text { small/medium-sized businesses }\end{array}$ & 4.09 & 0.82 & High & 1 \\
\hline Hotel development should attract more investment for local communities & 3.98 & 0.82 & High & 4 \\
\hline $\begin{array}{l}\text { Hotel development should create more jobs for local population and local } \\
\text { communities }\end{array}$ & 4.05 & 0.86 & High & 2 \\
\hline Long-term planning & Mean & SD & Level & Order \\
\hline $\begin{array}{l}\text { I think we need to take a long-term view when planning destination tourism } \\
\text { development }\end{array}$ & 3.99 & 0.80 & High & 2 \\
\hline $\begin{array}{l}\text { I believe that successful management of tourism growth requires advanced planning } \\
\text { strategy }\end{array}$ & 4.04 & 0.82 & High & 1 \\
\hline Community development \& involvement & Mean & SD & Level & Order \\
\hline $\begin{array}{l}\text { It is not appropriate when tourism development, e.g. hotel development decisions, } \\
\text { does not involve everyone in the community }\end{array}$ & 4.04 & 0.91 & High & 1 \\
\hline $\begin{array}{l}\text { For successful tourism development, including hotels, full community participation } \\
\text { and involvement is required }\end{array}$ & 3.88 & 0.73 & High & 2 \\
\hline Amenities development \& quality tourism experiences & Mean & SD & Level & Order \\
\hline $\begin{array}{l}\text { Hotel development should provide incentives for government and local communities } \\
\text { to restore historical buildings }\end{array}$ & 3.95 & 0.81 & High & 2 \\
\hline $\begin{array}{l}\text { Hotel development should encourage development of more recreational facilities for } \\
\text { local residents and visitors }\end{array}$ & 4.04 & 0.87 & High & 1 \\
\hline $\begin{array}{l}\text { The tourism industry, particularly hotels, must ensure future good quality tourism } \\
\text { experiences }\end{array}$ & 3.91 & 0.79 & High & 3 \\
\hline Local prices \& tax revenue & Mean & SD & Level & Order \\
\hline Hotel development may increase the price of goods and services in an area & 3.98 & 0.83 & High & 2 \\
\hline $\begin{array}{l}\text { Hotel development should create additional tax revenues from tourists for local } \\
\text { government }\end{array}$ & 4.08 & 0.79 & High & 1 \\
\hline Sustainable tourism development & Mean & SD & Level & Order \\
\hline I support the development of community-based sustainable tourism initiatives & 4.11 & 0.80 & High & 1 \\
\hline I participate in sustainable tourism-related plans and development & 3.98 & 0.85 & High & 4 \\
\hline I participate in cultural exchanges between local residents and visitors & 4.08 & 0.90 & High & 3 \\
\hline I cooperate with tourism planning and development initiatives & 4.10 & 0.87 & High & 2 \\
\hline I participate in the promotion of environmental education and conservation & 3.89 & 0.78 & High & 5 \\
\hline
\end{tabular}

\subsection{Hypotheses Testing Results}

The current research is mainly seeking to investigate the impact of hotel development on sustainable tourism development in Aqaba hotels in Jordan. Consequently, in order to test the main hypothesis developed for this study, a simple regression technique was used as demonstrated in Table 5.

Table 5. Regression analysis: Sustainable tourism development as dependent variable

\begin{tabular}{cccccccc}
\hline Dependent variable & $\mathrm{R}$ & $\mathbf{R}^{\mathbf{2}}$ & $\mathrm{F}$ & $\mathrm{Sig}(\mathbf{f})$ & $\boldsymbol{\beta}$ & $\mathrm{t}$ & Sig $(\mathbf{t})$ \\
\hline Sustainable tourism development & 0.540 & 0.291 & 152.334 & $0.000 \mathrm{a}$ & 0.362 & 5.003 & $0.000 \mathrm{~b}$ \\
\hline
\end{tabular}

a. Predictors: (Constant), Hotel development

b. Dependent variable: Sustainable tourism development 
Refer to Table 5 the correlation coefficient $\mathrm{R}=0.540$ indicates that there is a positive correlation between hotel development and sustainable tourism development. The R2 indicated the generalizability of the model. It allows us to generalize the results taken from the respondents to the whole population. In this case it equals 0.291 . The results showed that F-ratio for these data is equal to 152.334 , which is statistically significant at $p<0.05$. Therefore, we conclude that there is a statistically significant effect of hotel development on sustainable tourism development. The $\beta$ indicates the contribution of the predictor (i.e. the independent variable) to the model. Table 5 shows the standardized coefficients for the hotel development. The value of $\beta$ is 0.362 , which does have a significant effect on sustainable tourism development.

Hypotheses H2A, H2B, H2C, H2D, H2E, and H2F argued that there is a significant difference in the impact of hotel development on sustainable tourism development due to gender, age, educational level, personal income, work position, and hotel classification. Independent Samples T-test was employed in order to investigate if there any significant differences in the impact of hotel development on sustainable tourism development that can be attributed to gender. Also, ANOVA test was employed to examine if there any significant differences in the impact hotel development on sustainable tourism development that can be attributed to age, educational level, personal income, work position, and hotel classification. Results of T-test, shown in Table 6, indicated that there is no significant difference in the impact of hotel development on sustainable tourism development that can be attributed to gender. In addition, results of ANOVA tests, shown in Tables 7-11, indicated that there are no significant differences in the impact hotel development on sustainable tourism development in favor of age, educational level, personal income, work position, and hotel classification.

Table 6. T-test of hotel development on sustainable tourism development due to gender

\begin{tabular}{|c|c|c|c|c|c|c|c|c|c|}
\hline \multirow{2}{*}{ Variables } & \multicolumn{3}{|c|}{ Male } & \multicolumn{3}{|c|}{ Female } & \multirow{2}{*}{$\mathbf{T}$} & \multirow{2}{*}{ df } & \multirow{2}{*}{ Sig. } \\
\hline & $\mathbf{N}$ & Mean & Std. Dev. & $\mathbf{N}$ & Mean & Std. Dev. & & & \\
\hline $\begin{array}{l}\text { Sustainable tourism } \\
\text { development }\end{array}$ & 165 & 4.0384 & 0.35000 & 5 & 4.0667 & 0.25276 & 0.179 & 168.478 & 0.858 \\
\hline
\end{tabular}

Table 7. ANOVA Analysis hotel development on sustainable tourism development due to age

\begin{tabular}{ccccccc}
\hline Variables & \multicolumn{2}{c}{$\begin{array}{c}\text { Sum of } \\
\text { Squares }\end{array}$} & Df & $\begin{array}{c}\text { Mean } \\
\text { Square }\end{array}$ & F & Sig. \\
\hline $\begin{array}{c}\text { Sustainable tourism } \\
\text { development }\end{array}$ & $\begin{array}{c}\text { Between } \\
\text { Groups }\end{array}$ & 0.081 & 3 & 0.027 & 0.220 & 0.882 \\
\cline { 2 - 7 } & $\begin{array}{c}\text { Within } \\
\text { Groups }\end{array}$ & 20.269 & 166 & 0.122 & & \\
\cline { 2 - 7 } & Total & 20.350 & 169 & & & \\
\hline
\end{tabular}

Table 8. ANOVA Analysis hotel development on sustainable tourism development due to educational level

\begin{tabular}{ccccccc}
\hline Variables & \multicolumn{1}{c}{$\begin{array}{c}\text { Sum of } \\
\text { Squares }\end{array}$} & Df & $\begin{array}{c}\text { Mean } \\
\text { Square }\end{array}$ & F & Sig. \\
\hline $\begin{array}{c}\text { Sustainable tourism } \\
\text { development }\end{array}$ & $\begin{array}{c}\text { Between } \\
\text { Groups }\end{array}$ & 0.066 & 2 & 0.033 & 0.270 & 0.764 \\
\cline { 2 - 5 } & Within & 20.284 & 167 & 0.121 & & \\
& & & & & \\
\cline { 2 - 7 } & Groups & Total & 20.350 & 169 & & \\
\hline
\end{tabular}


Table 9. ANOVA Analysis hotel development on sustainable tourism development due to personal income

\begin{tabular}{ccccccc}
\hline Variables & \multicolumn{2}{c}{$\begin{array}{c}\text { Sum of } \\
\text { Squares }\end{array}$} & Df & $\begin{array}{c}\text { Mean } \\
\text { Square }\end{array}$ & F & Sig. \\
\hline $\begin{array}{c}\text { Sustainable tourism } \\
\text { development }\end{array}$ & $\begin{array}{c}\text { Between } \\
\text { Groups }\end{array}$ & 0.089 & 2 & 0.044 & 0.366 & 0.694 \\
\cline { 2 - 5 } & $\begin{array}{c}\text { Within } \\
\text { Groups }\end{array}$ & 20.261 & 167 & 0.121 & & \\
\cline { 2 - 5 } & Total & 20.350 & 169 & & & \\
\hline
\end{tabular}

Table 10. ANOVA Analysis hotel development on sustainable tourism development due to work position

\begin{tabular}{ccccccc}
\hline Variables & \multicolumn{1}{c}{$\begin{array}{c}\text { Sum of } \\
\text { Squares }\end{array}$} & Df & $\begin{array}{c}\text { Mean } \\
\text { Square }\end{array}$ & F & Sig. \\
\hline $\begin{array}{c}\text { Sustainable tourism } \\
\text { development }\end{array}$ & $\begin{array}{c}\text { Between } \\
\text { Groups }\end{array}$ & 0.378 & 3 & 0.126 & 1.048 & 0.373 \\
\cline { 2 - 5 } & $\begin{array}{c}\text { Within } \\
\text { Groups }\end{array}$ & 19.971 & 166 & 0.120 & & \\
\cline { 2 - 5 } & Total & 20.350 & 169 & & & \\
\hline
\end{tabular}

Table 11. ANOVA Analysis hotel development on sustainable tourism development due to hotel classification

\begin{tabular}{ccccccc}
\hline Variables & \multicolumn{1}{c}{$\begin{array}{c}\text { Sum of } \\
\text { Squares }\end{array}$} & Df & $\begin{array}{c}\text { Mean } \\
\text { Square }\end{array}$ & F & Sig. \\
\hline $\begin{array}{c}\text { Sustainable tourism } \\
\text { development }\end{array}$ & $\begin{array}{c}\text { Between } \\
\text { Groups }\end{array}$ & 0.007 & 2 & 0.004 & 0.030 & 0.971 \\
\cline { 2 - 5 } & $\begin{array}{c}\text { Within } \\
\text { Groups }\end{array}$ & 20.342 & 167 & 0.122 & & \\
\cline { 2 - 5 } & Total & 20.350 & 169 & & & \\
\hline
\end{tabular}

\section{Discussion and Conclusions}

Sustainable tourism development concept is connected with specific issues for identification tourism development strategic tools upon sustainable regional development. According to the UNESCO, the concept of sustainable tourism development is related to principles such as intra- and inter- generational equity, has been widely applied to economic sectors, mainly and sustainable tourism. Sustainable tourism development means the optimal use of social, natural, cultural and financial resources for national development on an equitable and self-sustaining basis to provide a unique visitor experience and an improved quality of life through partnerships among local government, private sector and communities (Rukuižienè, 2014).

The direct and indirect economic benefits of tourism can also generate positive social and cultural impacts as it can serve as a supportive force for peace, foster pride in cultural traditions and help avoid urban relocation by creating local jobs including improved standards of living and health, and educational opportunities, promotion of arts and crafts, and environmental awareness in local communities. However, changes often occur in community structure, family relationships, collective traditional life styles, ceremonies and morality and the appearance of traffic congestion, noise pollution, crime and loss of cultural identity (Wilkinson, 2007; Prayag, et al., 2010).

Tourism has a variety of economic impacts and economic benefits. It is generally accepted that tourism provides considerable economic benefits, such as foreign exchange earnings, employment generation for locals, investment opportunities, tax revenues for government and hotel development and tourism impacts development of small and medium enterprises for countries, regions and communities but among its notable negative economic impacts are dependence on leakage, infrastructure cost, increase in price and seasonal character for jobs. The most direct effects occur within the primary tourism sectors -lodging, restaurants, transportation, amusements, and retail trade. Through secondary effects, tourism affects most sectors of the economy. An economic impact analysis of tourism activity normally focuses on changes in sales, income, and employment in a region resulting from tourism activity. Tourism 
development can put pressure on natural resources when it increases consumption in areas where resources are already scarce, negative impacts from tourism occur when the level of visitor use is greater than the environment's ability to cope with this use within the acceptable limits of change. Uncontrolled conventional tourism poses potential threats to many natural areas around the world. It can put enormous pressure on an area and lead to impacts such as soil erosion, increased pollution, discharges into the sea, natural habitat loss, increased pressure on endangered species and heightened vulnerability to forest fires. It often puts a strain on water resources, and it can force local populations to compete for the use of critical resources. In order to minimize the negative impacts local governments, tourism and environmental organizations and business sector itself should be familiar with environmental resource management system and the carrying capacity system.

Community involvement describes the extent to which residents are involved in sharing issues about their lives with their communities. Several studies have assessed the support of the host residents for tourism development with a focus on the extent to which these residents are involved in tourism community involvement can be argued as a critical factor in the development of community based tourism. Indeed, community participation plays a significant role in the sustainable development of community-based tourism because community participation can increase the value of a community by enhancing the positive effects of tourism and reducing its negative effects. Tourism studies indicate that engaging the local community in management and decision making can convince the community of the need to integrate tourism into the local economy indicated that the involvement of the community in tourism provides more opportunities for the host residents to benefit from tourism development. Last but not least sustainability is attracting and increasing attention within the global hotel industry, but there are marked variations in the volume and the detail of the data and information posted by the top hotel chains. Although the majority of the leading hotel chains claim strong commitments to sustainability, several of them also recognize, either explicitly or implicitly, that they are at the beginning of what may be a lengthy and arduous journey, and as such a range of issues merit discussion. Firstly, the way in which the world's leading hotel chains construct their definitions of sustainability merits attention. These definitions can be interpreted as being developed around efficiency and a commitment to securing competitive advantage within the marketplace, and they reflect business demands rather than fundamental concerns for sustainability or for the maintenance and enhancement of natural eco systems. While a number of the top hotel chains' environmental commitments are designed to reduce natural resource consumption, for example, they also produce cost savings. At the same time, commitments to staff development programmers and to diversity in the workplace encourage stability and loyalty amongst the workforce. Secondly, given the range of sustainability commitments being pursued by the leading hotel chains, it can be difficult to align various targets and goals. At the corporate level, individual hotel, managers who are looking to deliver on business deadlines and targets may, if facing problems with scheduling staff, demand that employees work hours and days that are not consistent with their work life balance or refuse to allow employees to attend staff development programmers and finally, there are issues concerning the way the world's leading hotel chains report on and provide information on sustainability. Generally, the accent is on providing a simple narrative of sustainability commitments and achievements. Sometimes such narratives are illustrated with simple statistics and case studies, and photographs and simple diagrams are widely used to illustrate general themes.

To sum up, this study aimed to identify the impact of hotel development on sustainable tourism development. Results of T-test, shown in Table 6, indicated that there is no significant difference in the impact of hotel development on sustainable tourism development that can be attributed to gender. In addition, results of ANOVA tests, shown in Tables 7-11, indicated that there are no significant differences in the impact hotel development on sustainable tourism development in favor of age, educational level, personal income, work position, and hotel classification it also indicated that hoteliers acknowledge that hotel development can have negative environmental impacts, but they also believe that government and the private sector should share the role of managing such impacts. To promote sustainable tourism development in the hotel industry may therefore require more public and private sector partnerships, initiatives and sharing of best practices among hotel companies the findings show high levels of agreement with statements such as government and hoteliers should further should encourage and strengthen efforts for environmental conservation. Therefore, a shared role between private sector, with governments and direct control of hotels, tends to be the most appropriate solution for environmental protection and sustainable tourism development but tests showed that in Table 3 there is a low means of negative social cultural and economic impacts hoteliers disagreed that hotel development can have negative social impacts and negative economic impacts of hotel development this can be explained by the fact that tourism has contributed significantly to the economic development hoteliers are therefore more inclined to perceive positive than negative economic impacts. As for their neutral perceptions of negative cultural impacts, this should be considered along with the disagreement levels 
expressed for negative social impacts however, hotel developers should not assume that sustainable tourism development will automatically be fostered by improving the environment or product quality or by keeping alive old traditions and cultural expressions of local communities while hoteliers perceive the impacts of hotel development to be mostly positive, achieving sustainability will require management of economic, cultural and social impacts. Therefore, hoteliers should consider a long term view of tourism planning and hotel development plans and test showed that there is a high means for long term planning that means that they are already considering that.

The investigation results about sustainable tourism environment are focused on several inherent challenges in applying the concept of sustainable tourism development to regional tourism industry. Nowadays the regional tourism industry is developing by using some sustainable tools the global partnership networking, green economy pillars, which makes easier way to manage tourism information and reveal structural market changes. Tourism environment serves also for contribution to sustainable regional development bringing people into closer contact with nature. Finally, descriptive and general indicators are pointing to the difficulties to investigate properly the sector impacts for sustainable tourism development. Such diversity of activities in regional level leads on findings on different sustainable tourism impacts, with the identification of positive and negative impacts. Their evaluation is required for maintenance the framework of national tourism industry with new findings for improving it by clustering.

The subjects of investigation in this study were located in Aqaba Jordan. This study did not test technological factors nor it did test all organizational factors and focused particularly on hotel management development capabilities, and top and middle management support for sustainable tourism practices. Hence, to gain a more in-depth understanding of the factors that influence sustainable development implementation, future studies should shed the light on the role of technological factors, and additional organizational factors. For instance, "sustainability mission" as being "to benefit this and future generations by actively managing our business through the lens of sustainability" and stresses that nowadays technology is a big part of tourism and hotel industry. Therefore, future study could assess the impact of technology development on hotel management development and sustainable tourism practices implementation. These calls are supported by several researchers such as Gold, et al. (2001); Jones, et al. (2014); and Migdadi, et al. (2015). Furthermore, several researchers consider the information systems and in particular the information technology (IT) and its flexibility as an enabler to achieve the desired competitive advantages, and as a crucial support to operational and strategic business decisions (Al Azmi, et al., 2012; Alenezi, et al., 2015; Alkalha, et al., 2012; Almajali \& Tarhini, 2016; Altamony et al., 2012; Kateb, et al., 2015; Maqableh \& Karajeh, 2014a, 2014b; Masa'deh, 2012,; Masa'deh, et al., 2016; Obeidat, et al., 2013; Shannak, et al., 2010, 2012a, 2012b; Tarhini et al., 2016; Vratskikh, et al., 2016); thus further research is required to examine the role of such IT applications in enhancing the managerial decisions. In addition, scholars (e.g. Masa'deh, et al. 2008; Hunaiti, et al., 2009; Masa'deh \& Kuk, 2009; Alshurideh, et al., 2012; Hajir, et al., 2015; Kannan \& Gharibeh, 2013; Masa'deh \& Shannak, 2012; Masa'deh, et al. 2013; Masa'deh, et al. 2017; Obeidat, et al., 2012, 2016; Shannak \& Alkour, 2012; Tarhini, et al., 2015) emphasize the need for large firms to integrate their IT systems with their KM strategies and processes in order to survive in their highly competitive business environments, which in turn could accelerate the managerial decisions as well.

\section{References}

Abbasi, M. S., Elyas, T., \& Shah, F. (2015). Impact of individualism and collectivism over the individual's technology acceptance behaviour: A multi-group analysis between Pakistan and Turkey. Journal of Enterprise Information Management, 28(6), 747-768. https://doi.org/10.1108/JEIM-12-2014-0124

Al Azmi, N., Al-Lozi, M., Al-Zu'bi, Z., Dahiyat, S., \& Masa'deh, R. (2012). Patients Attitudes toward Service Quality and its Impact on their Satisfaction in Physical Therapy in KSA Hospitals. European Journal of Social Sciences, 34(2), 300-314.

Al-Badi, A., \& Al-Kaaf, W. (2017). Financial Incentives for Adopting Cloud Computing in Higher Educational Institutions. Asian Social Science, 13(4), 162-174. https://doi.org/10.5539/ass.v13n4p162

Al-Badi, A., \& Al-Sawaei, S. (2017). Utilizing Social Media to Encourage Domestic Tourism in Oman. International Journal of Business and Management, 12(4), 84-94. https://doi.org/10.5539/ijbm.v12n4p84

Al-Badi, A. H., \& Al-Qayoudhi, W. S. (2014). Adoption of social networks in business: Study of users and potential users in Oman. The International Business \& Economics Research Journal (Online), 13(2), 401-415. https://doi.org/10.19030/iber.v13i2.8457

Al-Dmour, R., \& Obeidat, B. (2015). Strategic IT-Business Alignment as Managers' Explorative and Ecploitative 
Strategies. European Scientific Journal, 11(7), 437-457

Al-Dmour, H., Al-Madani, S., Alansari, I., \& Al-Dmour, R. (2016). Factors Affecting the Effectiveness of Cause-Related Marketing Campaign: Moderating Effect of Sponsor-Cause Congruence. International Journal of Marketing Studies, 8(5), 114-127. https://doi.org/10.5539/ijms.v8n5p114

Alenezi, H., Masa'deh, R. Alalwan, A., \& Al-Qirim, N. (2017). Factors Affecting e-Government Adoption in Kuwait: A Qualitative study. Electronic Journal of e-Government, 15(2), 84-102.

Alenezi, H., Tarhini, A., \& Masa'deh, R. (2015). Investigating the Strategic Relationship between Information Quality and E-Government Benefits: A Literature Review. International Review of Social Sciences and Humanities, 9(1), 33-50.

Alkalha, Z., Al-Zu'bi, Z., Al-Dmour, H., \& Alshurideh, M. (2012). Investigating the Effects of Human Resource Policies on Organizational Performance: An Empirical Study on Commercial Banks Operating in Jordan. European Journal of Economics, Finance and Administrative Sciences, 51, 44-64.

Allam, M., \& Elyas, T. (2016). Perceptions of Using Social Media as an ELT Tool among EFL Teachers in the Saudi Context. English Language Teaching, 9(7), 1-9. https://doi.org/10.5539/elt.v9n7p1

Almajali, D., \& Tarhini, A. (2016). Antecedents of ERP Systems Implementation Success: A Study on Jordanian Healthcare Sector. Journal of Enterprise Information Management, 29(4), 549-565.

Al-Mukhaini, E. M., Al-Qayoudhi, W. S., \& Al-Badi, A. H. (2014). Adoption of social networking in education: A study of the use of social networks by higher education students in Oman. Journal of International Education Research, 10(2), 143-155. https://doi.org/10.19030/jier.v10i2.8516

Al-Qirim, M., Rouibah, K., Serhani, M. A., Yammahi, A. R., \& Yammahi, M. A. (2017). Towards a Personality Understanding of Information Technology Students and their IT Learning in UAE University. Education and Information Technologies, 1-12. https://doi.org/10.1007/s10639-017-9578-1

Al-Qirim, N., Rouibah, K., Serhani, M. A., Yammahi, A. R., \& Yammahi, M. A. (2017). Learning Orientations of IT Higher Education Students in UAE University. Education and Information Technologies, 1-14. https://doi.org/10.1007/s10639-017-9589-y

Al-Qirim N., Tarhini, A., \& Rouibah, K. (2017). Determinants of Big Data Adoption and Success. In International Conference on Communications and Future Internet (ICCFI 2017). Jeju Island, South Korea, 10-13 August.

Alqahtani, M. A., Al-Badi, A. H., \& Mayhew, P. J. (2012). The Enablers and Disablers of E-Commerce: Consumers' Perspectives. The Electronic Journal of Information Systems in Developing Countries, 54(1), 1-25.

Alrowwad, A., Obeidat, B.Y., \& Aqqad, N. (2017). The impact of transformational leadership on organizational performance via the mediating role of corporate social responsibility: A structural equation modeling approach. International Business Research, 10(1), 199-221. https://doi.org/10.5539/ibr.v10n1p199

Alshurideh, M., Masa'deh, R., \& Alkurdi, B. (2012). The Effect of Customer Satisfaction on Customer Retention in the Jordanian Mobile Market: An Empirical Investigation. European Journal of Economics, Finance and Administrative Sciences, 47, 69-78.

Altamony, H., Alshurideh, M., \& Obeidat, B. (2012). Information Systems for Competitive Advantage: Implementation of an Organizational Strategic Management Process. Proceedings of the 18th IBIMA Conference on Innovation and Sustainable Economic Competitive Advantage: From Regional Development to World Economic, Istanbul, Turkey, 9th-10th May.

Altamony, H., Al-Salti, Z., Gharaibeh, A., \& Elyas, T. (2016). The relationship between Change Management Strategy and Successful Enterprise Resource Planning (ERP) Implementations: A Theoretical Perspective. International Journal of Business Management and Economic Research, 7(4), 690-703.

Bagozzi, R., \& Yi, Y. (1988). On the Evaluation of Structural Evaluation Models. Journal of the Academy of Marketing Science, 16(1), 74-94. https://doi.org/10.1007/BF02723327

Bisharat, H., Obeidat, B.Y., Alrowwad, A., Tarhini, A., \& Mukattash, I. (2017). The Effect of Human Resource Management Practices on Organizational Commitment in Chain Pharmacies in Jordan. International Journal of Business and Management, 12(1), 50-67. https://doi.org/10.5539/ijbm.v12n1p50

Creswell, J. (2009). Research Design: Qualitative, Quantitative, and Mixed Methods Approaches (3rd ed.). Thousand Oaks: Sage Publications.

El-Masri, M., \& Tarhini, A. (2015). A Design Science Approach to Gamify Education: From Games to Platforms. 
Twenty-Third European Conference on Information Systems (ECIS), Münster, Germany. 26-29 May 2015.

El-Masri, M., \& Tarhini, A. (2017). Factors affecting the adoption of e-learning systems in Qatar and USA: Extending the Unified Theory of Acceptance and Use of Technology 2 (UTAUT2). Educational Technology Research and Development, 65(3), 743-763. https://doi.org/10.1007/s11423-016-9508-8

El-Masri, M., Orozco, J., \& Tarhini, A. (2015). The Impact of IS-Business Alignment Practices on Organizational Choice of IS-Business Alignment Strategies. The 19th Pacific Asia Conference on Information Systems (PACIS 2015), Paper 215, Singapore, 6-9 July 2015.

Elyas, T., \& Picard, P. (2012). Teaching and Moral Tradition in Saudi Arabia: A Paradigm of Struggle or Pathway towards Globalization?. Procedia - Social and Behavioral Sciences, 41, 1083-1086.

Fedai, L., Daglı, G., Altınay, Z., \& Altınay, F. (2017). The examination of occupational burnout and job satisfaction of the physical education teachers. International Journal of Economic Perspectives, 11(1), 12-26.

García-Pozo, A., Sánchez- Ollero, J-L., \& Marchante-Mera, A. (2013). Environmental Sustainability Measures and their Impact on Hotel Room Pricing in Andalusia (Southern Spain). Environmental Engineering and Management Journal, 12(10), 1971-1978.

Gold, A.H., Malhotra, A., \& Segars, A.H. (2001). Knowledge Management: An Organizational Capabilities Perspective. Journal of Management Information Systems, $18(1), \quad 185-214$. https://doi.org/10.1080/07421222.2001.11045669

Hajir, J., Obeidat, B., \& Al-dalahmeh, M. (2015). The Role of Knowledge Management Infrastructure in Enhancing Innovation at Mobile Telecommunication Companies in Jordan. European Journal of Social Sciences, 50(3), 313-330.

Hamoud, M., Akour, M. A., \& Al-Salti, Z. (2016). Developing the Main Knowledge Management Process via Social Media in the IT Organisations: A Conceptual Perspective. International Journal of Business Administration, $7(5), 49-64$

Hassouna, M., Elyas, T., \& Abou Trab, M. S. (2015). Customer Churn in Mobile Markets: A Comparison of Techniques. International Business Research, 8(6), 224-237. https://doi.org/10.5539/ibr.v8n6p224

Hussian, A., Elyas, T., \& Nasseef, O. (2013). Research Paradigms: A Slippery Slope for Fresh Researchers. Life Science Journal, 10(4), 2374-2381.

Hunaiti, Z., Mansour, M., \& Al-Nawafleh. (2009). Electronic Commerce Adoption Barriers in Small and Medium-Sized Enterprises (SMEs) in Developing Countries: The Case of Libya. IBIMA Business Review, 2(5), $37-45$.

Jones, P., Hillier, D., \& Comfort, D. (2014). Sustainability in the Global Hotel Industry. International Journal of Contemporary Hospitality Management, 26(1), 5-17. https://doi.org/10.1108/IJCHM-10-2012-0180

Kanaan, R., \& Gharibeh, A. (2013). The Impact of Knowledge Sharing Enablers on Knowledge Sharing Capability: An Empirical Study on Jordanian Telecommunication Firms. European Scientific Journal, 9(22), $237-258$.

Kasimu, A.B., Zaiton, S., \& Hassan, H. (2012). Hotels Involvement in Sustainable Tourism Practices in Klang Valley, Malaysia. International Journal of Economics and Management, 6(1), 21-34.

Kateb, M., Swies, R., Obeidat, B., \& Maqableh, M. (2015). An Investigation on the Critical Factors of Information System Implementation in Jordanian Information Technology Companies. European Journal of Business and Management, 7(36), 11-28.

Lee, T. (2013). Influence Analysis of Community Resident Support for Sustainable Tourism Development. Tourism Management, 34, 37-46. https://doi.org/10.1016/j.tourman.2012.03.007

Mahadeen, B., Al-Dmour, R., \& Obeidat, B. Y. (2016). Examining the effect of the Organization's Internal Control System on Organizational Effectiveness: A Jordanian empirical study. International Journal of Business Administration, 7(6), 22-41. https://doi.org/10.5430/ijba.v7n6p22

Maqableh, M., \& Karajeh, H. (2014a). Job Scheduling for Cloud Computing Using Neural Networks. Communications and Network, 6(3), 191. https://doi.org/10.4236/cn.2014.63021

Maqableh, M., \& Karajeh, H. (2014b). A Theoretical Perspective on the Relationship between Leadership Development, Knowledge Management Capability, and Firm Performance. Asian Social Science, 10(6), 128.

Masa'deh, R. (2013). The Impact of Information Technology Infrastructure Flexibility on Firm Performance: An Empirical Study of Jordanian Public Shareholding Firms. Jordan Journal of Business Administration, 4(2), 
204-224. https://doi.org/10.12816/0002054

Masa'deh, R., \& Kuk, G. (2009). Antecedents and Intermediaries between Strategic Alignment and Firm Performance. Conference of the Academy of Management Annual Meeting (AOM), Illinois, Chicago, USA.

Masa'deh, R., Gharaibeh, A., Maqableh, M., \& Karajeh, H. (2013a). An Empirical Study of Antecedents and Outcomes of Knowledge Sharing Capability in Jordanian Telecommunication Firms: A Structural Equation Modeling Approach. Life Science Journal, 10(4), 2284-2296.

Masa'deh, R., Hunaiti, Z., \& Bani Yaseen, A. (2008). An Integrative Model Linking IT-Business Strategic Alignment and Firm Performance: The Mediating Role of Pursuing Innovation and Knowledge Management Strategies. Communications of the International Business Information Management Association (IBIMA) Journal, 2(24), 180-187.

Masa'deh, R., Shannak, R., \& Maqableh, M. (2013b). A Structural Equation Modeling Approach for Determining Antecedents and Outcomes of Students' Attitude toward Mobile Commerce Adoption. Life Science Journal, $10(4), 2321-2333$.

Masa'deh, R., Tayeh, M., Al-Jarrah, I., \& Tarhini, A. (2015c). Accounting vs. Market-based Measures of Firm Performance Related to Information Technology Investments. International Review of Social Sciences and Humanities, 7(2), 129-145.

Masa'deh, R. (2012). The Impact of Management Information Systems (MIS) on Quality Assurance (QA): A Case Study in Jordan. International Journal of Information, Business, and Management, 5(4), 93-110.

Masa'deh, R., \& Shannak, R. (2012). Intermediary Effects of Knowledge Management Strategy and Learning Orientation on Strategic Alignment and Firm Performance. Research Journal of International Studies, 8(3), $112-128$.

Masa'deh, R., Gharaibeh, A., Tarhini, A., \& Obeidat, O. (2015a). Knowledge Sharing Capability: A Literature Review. In Fourth Scientific \& Research Conference on New Trends in Business, Management and Social Sciences, Istanbul, Turkey, 19-20 September 2015 (pp. 1-16). https://doi.org/10.2139/ssrn.2696924

Masa'deh, R., Obeidat, B., \& Tarhini, A. (2016). A Jordanian Empirical Study of the Associations among Transformational Leadership, Transactional Leadership, Knowledge Sharing, Job Performance, and Firm Performance: A Structural Equation Modelling Approach. Journal of Management Development, 35(5), 681-705. https://doi.org/10.1108/JMD-09-2015-0134

Masa'deh, R., Obeidat, B., Al-Dmour, R., \& Tarhini, A. (2015b). Knowledge Management Strategies as Intermediary Variables between IT-Business Strategic Alignment and Firm Performance. European Scientific Journal, 11(7), 344-368.

Masa'deh, R., Shannak, R., Maqableh, M., \& Tarhini, A. (2017). The Impact of Knowledge Management on Job Performance in Higher Education: The Case of the University of Jordan. Journal of Enterprise Information Management, 30(2), 244-262. https://doi.org/10.1108/JEIM-09-2015-0087

Migdadi, M., Al-Hujran, O., \& Aloudat, A. (2015). An Empirical Assessment of the Antecedents of Electronic-Business Implementation and the Resulting Organizational Performance. Internet Research, 26(3), 33-57.

Nassar, B., \& Arzoky, M. (2015). An Empirical Analysis of the Seasonal Patterns in Aggregate Directors' Trades. International Journal of Economics and Finance, 7(9), 59-84. https://doi.org/10.5539/ijef.v7n9p59

Obeidat, B. Y., Hashem, L., Alansari, I, \& Al-Salti, Z. (2016). The Effect of Knowledge Management Uses on Total Quality Management Practices: A Theoretical Perspective. Journal of Management and Strategy, 7(4), 18-29. https://doi.org/10.5430/jms.v7n4p18

Obeidat, B., Al-Suradi, M., \& Tarhini, A. (2016). The Impact of Knowledge Management on Innovation: An Empirical Study on Jordanian Consultancy Firms. Management Research Review, 39(10), 1214-1238.

Obeidat, B., El-Rimawi, S., Maqableh, M., \& Al-Jarrah, I. (2013). Evaluating the Profitability of the Islamic Banks in Jordan. European Journal of Economics, Finance and Administrative Sciences, 56, 27-36.

Obeidat, B., Sweis, R., Zyod, D., \& Alshurideh, M. (2012). The Effect of Perceived Service Quality on Customer Loyalty in Internet Service Providers in Jordan. Journal of Management Research, 4(4), 224-242.

Obeidat, B.Y., Al-Sarayrah, S., Al-Salti, Z., \& Sweis, R. (2016). Cultural Influence on Strategic Human Resource Management Practices: A Jordanian case study. International Business Research, 9(10), 94-114. https://doi.org/10.5539/ibr.v9n10p94 
Obeidat, B.Y., Tarhini, A., \& Aqqad, N. (2017). The impact of intellectual capital on innovation via the mediating role of knowledge management: A structural equation modeling approach. International Journal of Knowledge Management Studies, 8(2), 15-33.

Orozco, J., Tarhini, A., Masa'deh, R., \& Tarhini, T. (2015). A framework of IS/business alignment management practices to improve the design of IT Governance architectures. International Journal of Business and Management, 10(4), 1-12. https://doi.org/10.5539/ijbm.v10n4p1

Pallant, J. (2005). SPSS Survival Manual: A Step Guide to Data Analysis Using SPSS for Windows. Version 12. Chicago, Illinois: Open University Press.

Prayag, G., Dookhony-Ramphul, K., \& Maryeven, M. (2010). Hotel Development and Tourism Impacts in Mauritius: Hoteliers' Perspectives on Sustainable Tourism. Development Southern Africa, 27(5), 697-712. https://doi.org/10.1080/0376835X.2010.522832

Rukuižienè, R. (2014). Sustainable Tourism Development Implications to Local Economy. Regional Formation and Development Studies, 3(14), 170-177. https://doi.org/10.15181/rfds.v14i3.873

Sekaran, U., \& Bougie, R. (2013). Research Methods for Business: A Skill-Building Approach (6th ed.). New York: Wiley.

Shannak, R., \& Akour, M. (2012). Knowledge Management Strategy Building: Literature Review. European Scientific Journal, 8(15), 143-168.

Shannak, R., Al-Zu'bi, Z., Obeidat, B., Alshurideh, M., \& Altamony, H. (2012a). A Theoretical Perspective on the Relationship between Knowledge Management Systems, Customer Knowledge Management, and Firm Competitive Advantage. European Journal of Social Sciences, 32(4), 520-532.

Shannak, R., Obeidat, B., \& Almajali, D. (2010). Information Technology Investments: A Literature Review. Proceedings of the 14th IBIMA Conference on Global Business Transformation through Innovation and Knowledge Management: An Academic Perspective, Istanbul-Turkey, 23rd-24th June, pp.1356-1368.

Shannak, R., Obeidat, B., \& Masa'deh, R. (2012b). Culture and the Implementation Process of Strategic Decisions in Jordan. Journal of Management Research, 4(4), 257-281. https://doi.org/10.5296/jmr.v4i4.2160

Siti-Nabiha, A. K., George, R. A., Wahid, N., Amran, A., Mahadi, R., \& Abustan, I. (2014). The Development of a Green Practice Index for the Malaysian Hotel Industry. Issues in Social and Environmental Accounting, 8(1), 23-47. https://doi.org/10.22164/isea.v8i1.88

Tarhini, A., Al-Badi, A., Almajali, M., \& Alrabayaah, S. H. (2017). Factors influencing employees' Intention to use Cloud Computing. Journal of Management \& Strategy, 8(2), 47-62. https://doi.org/10.5430/jms.v8n2p47

Tarhini, A., Elyas, T., Akour, M. A., \& Al-Salti, Z. (2016). Technology, Demographic Characteristics and E-Learning Acceptance: A Conceptual Model Based on Extended Technology Acceptance Model. Higher Education Studies, 6(3), 72-89. https://doi.org/10.5539/hes.v6n3p72

Tarhini, A., El-Masri, M., Ali, M., \& Serrano, A. (2016). Extending the UTAUT model to understand the customers' acceptance and use of internet banking in Lebanon: A structural equation modeling approach. Information Technology and People, 29(4), 830-849. https://doi.org/10.1108/ITP-02-2014-0034

Tarhini, A., Arachchilage, N., \& Abbasi, M. (2015). A Critical Review of Theories and Models of Technology Adoption and Acceptance in Information System Research. International Journal of Technology Diffusion, 6(4), 58-77. https://doi.org/10.4018/IJTD.2015100104

Tarhini, A., Mgbemena, C., AbouTrab, M.S., \& Masa'deh, R. (2015). User Adoption of Online Banking in Nigeria: A Qualitative study. Journal of Internet Banking and Commerce, 20(3), 1-8.

Tarhini, A., Mohammed, A., \& Maqableh, M. (2016). Modeling Factors Affecting Student's Usage Behaviour of E-Learning Systems in Lebanon. International Journal of Business and Management, 11(2), 299-314. https://doi.org/10.5539/ijbm.v11n2p299

Vratskikh, I., Al-Lozi, M., \& Maqableh, M. (2016). The Impact of Emotional Intelligence on Job Performance via the Mediating Role of Job Satisfaction. International Journal of Business and Management, 5(4), 69-91. https://doi.org/10.5539/ijbm.v11n2p69

Wilkinson, P.F. (2007). Strategies for Tourism in Island Microstates. Annals of Tourism Research, 16, 153-177. https://doi.org/10.1016/0160-7383(89)90065-0 